\title{
Understanding Copper speciation and mobilization in soils and mine tailings from "Mineral La Aurora" in central Mexico: contributions from Synchrotron techniques
}

\author{
René Loredo Portales ${ }^{1}$, Gustavo Cruz Jiménez ${ }^{1}$, Hiram Castillo Michel, ${ }^{2,}$, \\ Diana Olivia Rocha Amador ${ }^{1}$, Katarina Vogel Mikuš ${ }^{3}$, Peter Kump ${ }^{4}$, Guadalupe de la Rosa ${ }^{5,+}$ \\ ${ }^{1}$ Department of Pharmacy, University of Guanajuato, Noria alta, 36050 Guanajuato, Guanajuato, Mexico. \\ ${ }_{2}^{2}$ ID 21, European Synchrotron Radiation Facility, Avenue des Martyrs 71, 3800 Grenoble, France. \\ ${ }^{3}$ Department of Biology, University of Ljubljana, Večna pot 111, 1000 Ljubljana, Slovenia. \\ ${ }^{4}$ Jožef Stefan Institute, Jamova 39, 1000 Ljubljana, Slovenia. \\ ${ }^{5}$ Biomedical and Electrical Engineering, University of Guanajuato, Lomas del Bosque 103, 37150 Leon, Guanajuato, Mexico. \\ *hiram.castillo_michel@esrf.fr \\ +gdelarosa@fisica.ugto.mx
}

\begin{abstract}
Potentially toxic elements are usually present in mine tailings in concentrations that may threat environmental and human health. In this research, mine tailings and soils from the mine "La Aurora" located in central Mexico were studied. This mine was exploited for $\mathrm{Pb}, \mathrm{Zn}, \mathrm{Ag}, \mathrm{Cu}$ and $\mathrm{Au}$ and abandoned since their last cycle in 1957. For this purpose, a combination of sequential extraction procedure (SEP), Flame Atomic Absorption Spectroscopy (FAAS), and X-ray synchrotron techniques (XAS) were used. Cu is present in mine tailings and soils in a range respectively between $125 \pm 21$ and $1763 \pm 10 \mathrm{mg} \cdot \mathrm{kg}^{-1}$ and $22 \pm 2$ and $88 \pm 5 \mathrm{mg} \cdot \mathrm{kg}^{-1}$. Repartition of Cu in mine tailings determined by SEP followed this general trend: Water soluble $>$ Residual $>$ Organic Bound $>$ Exchangeable $>$ Fe-Mn oxides bound $>$ Carbonates bound. In contrast, $\mathrm{Cu}$ in soils was mainly retained in the residual fraction and followed this general trend: Residual $>$ Organic bound $>$ Fe-Mn oxides bound $>$ Carbonates bound $>$ Water soluble $>$ Exchangeable. X-ray Absorption Near Edge Spectroscopy (XANES), showed that $\mathrm{Cu}$ is present as $\mathrm{Cu}^{2+}$, forming highly mobile species, and in minor proportion as $\mathrm{Cu}^{+}$species, as oxides and sulphides. $\mathrm{Cu}$ content in mine tailings is available for plants and bioaccessible with percentages higher than $50 \%$ in almost all the points tested. The calculated dose limit, that involves gastrointestinal disorders for chronic exposure is surpassed in all mine tailings tested.
\end{abstract}

Keywords: Copper, mine tailings, X-ray absorption spectroscopy.

Resumen

La concentración de Elementos Potencialmente Tóxicos en desechos mineros suele ser muy alta, en concentraciones que pueden constituir un riesgo para el medio y la salud humana. En este trabajo, se estudiaron jales y suelos del sitio de la mina "La Aurora", localizado en la región central de México. Este sitio minero fue explotado para $\mathrm{Pb}, \mathrm{Zn}, \mathrm{Ag}$, Cu y Au y abandonado desde su último ciclo en 1957. Con este propósito se empleó una combinación de Extracciones Secuenciales, Espectroscopía de Absorción Atómica de Flama y Técnicas de Luz Sincrotrón. La concentración de Cu determinada en los jales y suelos se encontró respectivamente en un rango de $125 \pm 21$ and $1763 \pm 10 \mathrm{mg} \cdot \mathrm{kg}^{-1}$ y $22 \pm 2$ a $88 \pm 5 \mathrm{mg} \cdot \mathrm{kg}^{-1}$. La distribución de Cu en los jales determinada por las Extracciones Secuenciales presento la siguiente tendencia: Soluble en agua $>$ Residual $>$ Unido a materia orgánica $>$ Intercambiable $>$ Unido a óxidos de Fe-Mn > Unido a carbonatos. En contraste, el Cu en el suelo es retenido principalmente en la fracción residual, como sigue: Residual > Unido a materia orgánica > Unido a óxidos de Fe-Mn > Unido a Carbonatos > Soluble en agua > Intercambiable. 
Los estudios de Espectroscopia de Absorción de rayos X cerca de la Estructura del Borde, mostraron que el Cu se encuentra presente formando especies altamente solubles de $\mathrm{Cu}^{2+}$ y en menor proporción como óxidos y sulfuros de Cu ${ }^{+}$. El Cu contenido en los jales se encuentra bioaccesible y disponible para las plantas, con porcentajes de mas del $50 \%$ en casi todos los puntos estudiados. Todos los jales muestreados superan el límite de la dosis calculada que involucra desordenes gastrointestinales por exposición crónica.

Palabras clave: Cobre, residuos mineros, espectroscopía de absorción de rayos $X$.

\section{Introduction}

Mine tailings are source of heavy metal pollution around the world and their residues constitute a risk for environmental and human health since they usually display elevated concentrations of Potentially Toxic Elements (PTE). The exposure of living organisms to these types of residues may result in physiological damage, risking their wellbeing. In the case of $\mathrm{Cu}$, which is in the focus of this study, high doses $\left(0.0731 \mathrm{mg} \cdot \mathrm{kg} \cdot \mathrm{day}^{-1}\right)$ in humans may induce gastrointestinal irritation and in some cases liver damage (ATSDR, 2004). $\mathrm{Cu}$ is also indirectly associated with a number of neurological disorders, including Alzheimer's and prion disease (Stern et al., 2007). In addition, it participates in cellular damage via oxidation by cupric ion (Freedman et al., 1986). In plants, Cu may cause morphological and physiological disorders including growth decrease and effects in photosynthetic activity. According to Mohanty et al. (1989), $\mathrm{Cu}$ acts as a potent inhibitor of photosynthetic electron transport at concentrations $\geq 0.06$ $\mathrm{mg} \mathrm{L}^{-1}$ in soil solution. The critical range for toxicity in leaves are between $20-30 \mathrm{mg} \cdot \mathrm{kg}^{-1}$ for crop species and around $18 \mathrm{mg} \cdot \mathrm{kg}^{-1}$ for grass species (Plenderleith and Bell, 1990; Alaoui-Sossé et al., 2004). In addition, plants, as the basis of food chain, could contribute to mobilize $\mathrm{Cu}$ and other PTE present in soils and waters (Ryan et al., 2013). In this context, mobilization is dependent on elemental speciation and the nature of the media containing the pollutant.

Reports on $\mathrm{Cu}$ levels in mine tailings vary significantly around the world. For example, in China and Zambia, $\mathrm{Cu}$ concentrations between 455 to $9979 \mathrm{mg} \cdot \mathrm{kg}^{-1}$ have been reported (Sracek et al., 2010; Zebo et al., 2012; Yao-Guang et al., 2013). The mobilization of PTE from mine tailing zones to surrounding soils represents a threat for the local environment. For example, Montenegro et al. (2009) found $\mathrm{Cu}$ levels around $375.1 \mathrm{mg} \cdot \mathrm{kg}^{-1}$, in soils near the Chilean $\mathrm{Cu}$ mine tailings of "La Cocinera". $\mathrm{Cu}$ content in soils exceeding $200 \mathrm{mg} \cdot \mathrm{kg}^{-1}$ are considered as anomalous (Bowie and Thorton, 1985). Regulations for $\mathrm{Cu}$ in soils are between 50 (Holland) to $1000 \mathrm{mg} \cdot \mathrm{kg}^{-1}$ (Spain) (Belmonte Serrato et al., 2010).

Mine tailings have been studied for environmental purposes with the use of physical methods such as Scanning Electron Microscopy (SEM), X-ray Fluorescence (XRF), and XAS. Yang et al. (2014) used XANES, Extended X-ray Absorption Fine Structure (EXAFS), micro X-ray
Fluorescence ( $\mu$-XRF) spectroscopy and Scanning Transmission X-ray Microscopy (STXM) to investigate speciation and distribution of $\mathrm{Cu}$ in mine tailings from Zhuji Country of Zhejiang province, China. Their results suggest that $\mathrm{Cu}$ is associated with Fe oxides, adsorbed to Fe(III) oxides by inner-sphere complexation. MamindyPajany et al. (2014) used micro X-ray Absorption Near Edge Structure ( $\mu$-XANES) and $\mu$ XRF spectroscopy to investigate the spatial distribution of $\mathrm{Ca}, \mathrm{Fe}, \mathrm{Ni}, \mathrm{Cu}$ and $\mathrm{Zn}$, in a biosolid-amended soil. They concluded that there $\mathrm{Cu}$ have a close relation with Fe oxy (hydr) oxides. Donner et al. (2011) also used XRF and XAS techniques to investigate the speciation of $\mathrm{Cu}$ and $\mathrm{Zn}$ in bio solids from Australia; they improved a combination of XANES, EXAFS and $\mu$-XRF imaging to understand elemental associations within bio solids. Their results suggest that $\mathrm{Cu}$ and $\mathrm{Zn}$ are closely associated with $\mathrm{Fe}$ and this is one of the mechanisms controlling their mobility. For a better understanding of $\mathrm{Cu}$ mobility and speciation it is necessary to perform experiments about bioaccessibility and phytoaccessibility in order to get information of $\mathrm{Cu}$ fractions susceptible of entering in to the food chain. In this work, we combined spectroscopic techniques and extractions procedures to elucidate the speciation of $\mathrm{Cu}$ in mine tailings and its mobilization to the near environment of the abandoned mine "La Aurora".

\section{Work area description}

The site of study is called "La Aurora" and is located 4 km NW of Xichú town, in Guanajuato, Mexico, $393071 \mathrm{~m}$ $\mathrm{N}$ and $2359296 \mathrm{~m} \mathrm{~W}$ (UTM). This zone belongs to a natural protected area called "Sierra Gorda" with high biodiversity of species and biological resources. Located at the central zone of the folded belt of Jurassic and Cretaceous carbonate rocks, elevations are between 900 to 2400 masl. The weather is semi arid with summer rains, and temperatures range between 18 to $22^{\circ} \mathrm{C}$. The Mine "La Aurora" was exploited for $\mathrm{Pb}, \mathrm{Zn}, \mathrm{Ag}, \mathrm{Cu}$ and $\mathrm{Au}$, and is abandoned since 1957 (SEMARNAT, 2005; Carrillo-Chávez et al., 2014).

\section{Methods}

3.1. Mine tailing and soil sampling

Samples of mine tailings were collected from 13 
sampling points, distributed over the mine tailing area and five points in soils located near the end of the mine tailings. Three more points were sampled in soils located at a distance of $1.5 \mathrm{~km}$ from the wastes as controls. Composites samples were taken at 1 and $30 \mathrm{~cm}$ depth per sampling point, except in soils where all samples are composites of $30 \mathrm{~cm}$ depth. Samples were dried at $50^{\circ} \mathrm{C}$ for $24 \mathrm{~h}$ and sieved in two particle sizes: $<0.25,<0.85 \mathrm{~mm}$ (mesh 60 and 20), according to the Mexican regulations for metal content determination in soils for remediation (NOM147-SEMARNAT/SSA1, 2007), and EPA method 3050b (US-EPA, 1996) for acid digestion of sediments, sludge and soils. All samples were transferred to the Toxicology Laboratory at the University of Guanajuato for analysis of metal contents and for different extraction procedures to get information, for example about bio and phytoaccessibility. In soil samples, $\mathrm{pH}$ values ranged $7.3-8.2$ and, in mine tailings, $2.8-6.6$. Additionally, $\mu$-XRF and $\mu$-XANES spectra have been measured using synchrotron radiation, due to limited amount of beamtime, this manuscript presents results from two mine tailing samples and one soil only.

\subsection{Total $\mathrm{Cu}$ content analysis}

Mine tailings and soil samples were analyzed using FAAS and XRF (only in selected samples for validation purposes) for total $\mathrm{Cu}$ content. For FAAS analysis, tailings and soil samples were digested under reflux according 3050b EPA method (US-EPA, 1996). $1 \mathrm{~g}$ of sample was weighed in a $50 \mathrm{~mL}$ polypropylene centrifuge tube and then $5 \mathrm{~mL}$ of $\mathrm{HNO}_{3}$ (Reagent grade, Fermont) were added. Mixtures were boiled for about $1 \mathrm{~h}$ with a reflux condenser. Later, $3 \mathrm{~mL}$ of $\mathrm{H}_{2} \mathrm{O}_{2}$ (30\%; Fermont) were added before boiling continued for about $1 \mathrm{~h}$ more. The residue was centrifuged at $3000 \mathrm{x}$ g and filtered with a $2.5 \mu \mathrm{m}$ membrane (Whatman (C), gauged to $10 \mathrm{~mL}$ of deionized water in a volumetric flask and stored at $4{ }^{\circ} \mathrm{C}$ in centrifuge tubes until analysis. FAAS analysis was carried out by flame technique at 324.8 $\mathrm{nm}$ with a lamp current of $4.0 \mathrm{~mA}$ and slit of $0.5 \mathrm{~nm}$ in a PerkinElmer HGA 800 and SpectrAA 220FS.

For XRF analysis 100 to $300 \mathrm{mg}$ of the powdered samples were pressed into pellets using a pellet die and hydraulic press. ${ }^{109} \mathrm{Cd}(25 \mathrm{mCi})$ (Isotope Products Laboratories, Valencia, USA) was used as the primary excitation sources for the analysis. The fluorescence radiation emitted was collected using an energy dispersive X-ray spectrometer, equipped with a $\mathrm{Si}(\mathrm{Li})$ detector (Canberra, 157 Meriden, USA), with a $25-\mu \mathrm{m}$-thick Be window. The XRF analysis was performed in air, and the samples were irradiated for 1000 to $5000 \mathrm{~s}$ to obtain spectra with sufficient statistics (Necemer et al., 2008). X-ray fluorescence spectra were analyzed with the iterative least squares programme (AXIL) (Van-Grieken, 1993), as included in the quantitative X-ray analysis system software package (Vekemans et al., 1994). Element quantification from the measured spectra was performed using the quantitative analysis of environmental samples based on fundamental parameters (IAEA, 2011). Quality assurance for the element analyses was performed using as standard reference material 2730a Montana Soil.

\subsection{Extraction procedures}

For chemical extraction procedures 4 mine tailing (T1, $\mathrm{T} 2, \mathrm{~T} 10, \mathrm{~T} 12), 2$ soil $(\mathrm{S} 1, \mathrm{~S} 2)$ and one reference (S1R) site samples were selected. Extractions were performed in composite and surface samples from both particle size fractions $<0.25,<0.85 \mathrm{~mm}$ (mesh 60 and 20). Bioaccessibility was determined only in the particle size $<$ $0.25 \mathrm{~mm}$ fraction (mesh 60), since this is the representative fraction of solids that may adhere to the hands of children and prone to be swallowed.

\subsubsection{Bioaccessibility}

Bioaccessibility was determined by quantifying the fraction of $\mathrm{Cu}$ that is soluble in a gastric media. This provides a measure of the oral exposure of $\mathrm{Cu}$. Gastric media extraction was performed according to the Mexican Regulation (NOM-147-SEMARNAT-SSA1, 2007). Gastric media was simulated by a solution of $0.4 \mathrm{M}$ Glycine (Reagent plus; Ultra Sigma), acidified with $\mathrm{HCl}$ at $\mathrm{pH} 1.5 \pm$ 0.05 (reagent grade; Fermont). $1 \mathrm{~g}$ of sample was weighed in a $1 \mathrm{~L}$ glass recipient in triplicate and then $100 \mathrm{~mL}$ of gastric media were added. Solutions were shaken at $30 \pm 2 \mathrm{rpm}$ at 37 ${ }^{\circ} \mathrm{C}$ for $1 \mathrm{~h}$. After this, $20 \mathrm{~mL}$ of extract were centrifuged at $3000 \mathrm{x}$ g and filtered with a $2.5 \mu \mathrm{m}$ membrane (Wathman (C) and stored at $4{ }^{\circ} \mathrm{C}$ until analysis with FAAS. We calculated the estimated dose for oral exposition in children, in order to establish the potential toxicity via soil ingestion. Data used for this purpose were taken of similar studies in the same region (central Mexico area); using a soil ingest of 200 $\mathrm{mg}$ day $^{-1}, 52 \mathrm{~h}$ of exposition and $52 \mathrm{~kg}$ weight for a child between 6 and 9 years (CEPIS, 1998).

\subsubsection{Phytoaccessibility}

Phytoaccessibility was determined by extraction with a solution of Low Weight Molecular Organic Acids (LWMOA), simulating a chemical rhizosphere environment. Organic acids control the solubility of some elements and therefore the possibility to get into the plant tissue. Composition of solution was described by Cieśliński et al. (1998): acetic acid $\left(\mathrm{C}_{2} \mathrm{H}_{4} \mathrm{O}_{2} ; 2898 \mathrm{mM}\right)$, succinic $\left(\mathrm{C}_{4} \mathrm{H}_{6} \mathrm{O}_{4}\right.$; $194 \mathrm{mM})$, oxalic $\left(\mathrm{H}_{2} \mathrm{C}_{2} \mathrm{O}_{4} ; 43 \mathrm{mM}\right)$, malic $\left(\mathrm{C}_{4} \mathrm{H}_{6} \mathrm{O}_{5} ; 39.8\right.$ $\mathrm{mM})$, tartaric $\left(\mathrm{C}_{4} \mathrm{H}_{6} \mathrm{O}_{6} ; 26.3 \mathrm{mM}\right)$, fumaric $\left(\mathrm{C}_{4} \mathrm{H}_{4} \mathrm{O}_{4} ; 12 \mathrm{mM}\right)$ and citric acid $\left(\mathrm{C}_{6} \mathrm{H}_{8} \mathrm{O}_{7} ; 6 \mathrm{mM}\right)$. Extraction was performed using $1 \mathrm{~g}$ of sample and the LWMOA solution in a 1:15 proportion ( $\mathrm{pH} 4.5 \pm 0.1)$. Solutions were shaken for $5 \mathrm{~h}$, centrifuged at $3000 \mathrm{x}$ g, filtered with a $2.5 \mu$ membrane (Whatman $\odot$ ), and stored at $4{ }^{\circ} \mathrm{C}$ until analysis by FAAS.

\subsubsection{Sequential Extraction Procedure}

Sequential extraction used for this purpose was a modified version of Tessier et al. (1979) for the speciation of 
particulate trace metals. $1 \mathrm{~g}$ of each sample was weighed and stored in a $50 \mathrm{~mL}$ centrifuge tube by triplicate. Extraction was performed as follows: 1) Water soluble, $15 \mathrm{~mL}$ of deionized water was added and stirred for $2 \mathrm{~h}$ at room temperature; 2) Exchangeable, $8 \mathrm{~mL}$ of $1 \mathrm{M} \mathrm{MgCl}_{2}(\mathrm{pH} 7.0)$ were added to the solid residue from the previous step, and stirred for $1 \mathrm{~h}$ at room temperature; 3 ) Carbonates bound, 8 $\mathrm{mL}$ of $1 \mathrm{M} \mathrm{NaOAc}$ (pH 5.0 with HOAc) were added to the solid residue from the previous step, and stirred for $5 \mathrm{~h}$ at room temperature; 4) Fe-Mn oxides bound, $15 \mathrm{~mL}$ of $0.04 \mathrm{M}$ $\mathrm{NH}_{2} \mathrm{OH} \cdot \mathrm{HCL}$ in $25 \%(\mathrm{v} / \mathrm{v}) \mathrm{HOAc}$ were added to the solid residue from the previous step, during $6 \mathrm{~h}$ at $96{ }^{\circ} \mathrm{C}$ with occasional stirring; 5) Organic bound, $3 \mathrm{~mL}$ of $0.02 \mathrm{M} \mathrm{HNO}_{3}$ and $5 \mathrm{~mL}$ of $30 \% \mathrm{H}_{2} \mathrm{O}_{2}\left(\mathrm{pH} 2\right.$ with $\left.\mathrm{HNO}_{3}\right)$, heated during 2 $\mathrm{h}$ at $85^{\circ} \mathrm{C}$ with occasional stirring, after that another $3 \mathrm{~mL}$ of $\mathrm{H}_{2} \mathrm{O}_{2}\left(\mathrm{pH} 2\right.$ with $\mathrm{HNO}_{3}$ ) was added, heated during $3 \mathrm{~h}$ at 85 ${ }^{\circ} \mathrm{C}$ with occasional stirring; 6) Residual was extracted with and acid extraction with $\mathrm{HNO}_{3}$ and $\mathrm{H}_{2} \mathrm{O}_{2}$. After each step solid residue was washed with $15 \mathrm{~mL}$ of deionized water, centrifuged at $3000 \times \mathrm{g}$, filtered with a $2.5 \mu$ membrane (Wathman (C), and stored at $4{ }^{\circ} \mathrm{C}$ until analysis by FAAS.

\subsection{Synchrotron analysis}

Synchrotron analyses were performed for two mine tailing (T1, T2) and one soil (S1) sample (surface and composite). Due to limited availability of beamtime preference was given to the particle size $<0.25 \mathrm{~mm}$ (mesh 60) fraction, which is the most prone to weathering processes.

\subsubsection{Bulk XAS}

XAS measurements were performed at the XAFS beamline of the Elettra Sincrotrone Trieste. All samples were pulverized and homogenized using an agate mortar, mixed with Boron nitride or Polivinil Pirrolidone and prepared as pellets. References were mounted on adhesive tape. The following reference compounds and minerals were used to compare against unknown samples: clinoclase $\left(\mathrm{Cu}_{3} \mathrm{AsO}_{4}(\mathrm{OH})_{3}\right)$, copper(II) sulfate/chalcanthite $\left(\mathrm{CuSO}_{4} \cdot 5 \mathrm{H}_{2} \mathrm{O}\right)$, copper(II) oxide $(\mathrm{CuO})$, copper (I) oxide $\left(\mathrm{CuO}_{2}\right)$, olivenite $\left(\mathrm{Cu}_{2} \mathrm{AsO}_{4} \mathrm{OH}\right)$, and copper acetate $\mathrm{Cu}\left(\mathrm{CH}_{3} \mathrm{COO}\right)_{2}$. Due to the high content of As we selected two of the most common copper arsenates found in oxidized zones of base metal deposits clinoclase and olivenite (Anthony et al., 2003). The latter were obtained from Excalibur minerals, the other reference substances were purchased as reagent grade chemicals from sigma Aldrich. XANES data acquisition was performed with the use of a Silicon Drift Detector (SDD; KETEK GmbH AXAS-M with an assembled $80 \mathrm{~mm}^{2} \mathrm{SDD}$ ) in fluorescence mode for diluted samples (soil), and in transmission mode for model compounds and samples with high $\mathrm{Cu}$ content. $\mathrm{Cu} \mathrm{K}$ edge $(8979 \mathrm{eV})$ was calibrated using a $\mathrm{Cu}^{0}$-foil and scanned 120 $\mathrm{eV}$ below the edge ( $5 \mathrm{eV}$ energy steps) and $220 \mathrm{eV}$ above the edge ( $0.2 \mathrm{eV}$ energy steps), energy was selected by a $\mathrm{Si}$
(111) double crystal monochromator. Multiple scans (2 10) were collected and averaged for each sample in order to obtain adequate signal to noise. XANES data analysis was performed using Athena (Ravel and Newville, 2005) programs. Normalized data was used for XANES and Linear Combination Fits (LCF). LCF were performed in the range -55 to $100 \mathrm{eV}$, using all possible combinations of references ( $3-4$ variables), all weights between $0-1$ and forced to sum 1 .

\subsection{2. $\mu$-XRF and $\mu$-XANES spectroscopy}

$\mu$-XRF mapping of $\mathrm{Cu}$ was performed at European Synchrotron Radiation Facility (ESRF) beamline ID21. Samples T1c60, T2c60, and S1c60 were scattered on the surface of sulphur free tape for analysis. The beam was focused with the use of a Fresnel zone plate to a size of $0.500 \times 0.900 \mu \mathrm{m}^{2}(\mathrm{VxH})$. Incident energy was $9.1 \mathrm{keV}$ and the fluorescence signal was detected by single element SDD $80 \mathrm{~mm}^{2}$ active area, Bruker detector. Well time and distance of the detector were optimized for each XRF map keeping the dead time below $15 \%$. The XRF data was processed using PyMCA software (Solé et al., 2007). The elemental distribution images were obtained by fitting the fluorescence emission peaks in the spectrum of each pixel and display the net intensity normalized by incoming beam for each element of interest. For $\mu$-XANES data acquisition the energy was selected using a Si (111) double crystal monochromator and scanned from 8950 to $9150 \mathrm{eV}$. The zone plate was translated in the beam axis in order to maintain the beam focus.

$\mu$-XRF mapping at $12.1 \mathrm{keV}$ was performed at the Advanced Light Source (ALS) beamline 10.3. (Marcus et al., 2004) in order to obtain co-localization with $\mathrm{Cu}$ and As. Sample T1c20 (<0.85 mm particle size) was embedded in epoxy resin, polished to $20 \mu \mathrm{m}$ thickness and detached from the glass substrate for analysis. Maps were recorded using a $4 \times 4 \mu \mathrm{m}(\mathrm{V} \times \mathrm{H})$ beam at $12.1 \mathrm{keV}$ with a $4 \times 4 \mu \mathrm{m}$ pixel size and a $30 \mathrm{~ms}$ dwell time. The fluorescence yield was measured with a seven-element germanium (Ge) solidstate fluorescence detector (Canberra $50 \mathrm{~mm}^{2}$ per element) and normalized by $\mathrm{I}_{0}$ and the dwell time.

\section{Results and discussion}

Total $\mathrm{Cu}$ content as determined by FAAS is shown in Table 1. For validation purposes selected samples were analyzed by XRF for total $\mathrm{Cu}$ content (XRF results in Table 3). Both methods agree in the values of $\mathrm{Cu}(\mathrm{p}<0.01)$ concentration and this supports the use of XRF as method for total quantification of $\mathrm{Cu}$ in mine tailings (for concentrations above tens of ppm). XRF is a non-destructive and least expensive technique compared to FAAS. Cu concentrations in mine tailings are in the range of $125 \pm 21$ and $1763 \pm 10$ $\mathrm{mg} \cdot \mathrm{kg}^{-1}$ and in soils between $22 \pm 5$ and $88 \pm 5 \mathrm{mg} \cdot \mathrm{kg}^{-1}$ (See Table 1). Soil reference samples collected from locations at $1.5 \mathrm{~km}$ distance from the mine tailings have $\mathrm{Cu}$ contents 
Copper speciation and mobilization in mine wastes in central Mexico

Table 1. Total $\mathrm{Cu}$ content in $\mathrm{mg} \cdot \mathrm{kg}^{-1}$ in mine tailings \pm S.D. in (T) soils (S) and reference (R) samples, collected at $1 \mathrm{~cm}(\mathrm{~s})$ and $30 \mathrm{~cm}(\mathrm{c})$ depth, grain sizes $<0.25 \mathrm{~mm}(60),<0.85 \mathrm{~mm}(20)$.

\begin{tabular}{|c|c|c|c|c|c|c|c|c|}
\hline \multirow[b]{2}{*}{ Fraction } & \multicolumn{2}{|c|}{$\mathrm{Cu} \mathrm{mg} \cdot \mathrm{kg}^{-1}$} & \multirow[b]{2}{*}{ Fraction } & \multicolumn{2}{|c|}{$\mathrm{Cu} \mathrm{mg} \cdot \mathrm{kg}^{-1}$} & \multirow[b]{2}{*}{ Fraction } & \multicolumn{2}{|c|}{$\mathrm{Cu} \mathrm{mg} \cdot \mathrm{kg}^{-1}$} \\
\hline & \multirow{2}{*}{60} & \multirow{2}{*}{20} & & \multirow{2}{*}{60} & \multirow{2}{*}{20} & & \multirow{2}{*}{60} & \multirow{2}{*}{20} \\
\hline Sample & & & Sample & & & Sample & & \\
\hline T1s & $628 \pm 21$ & $452 \pm 10$ & $\mathrm{~T} 7 \mathrm{~s}$ & $549 \pm 46$ & $564 \pm 49$ & $\mathrm{~T} 13 \mathrm{~s}$ & $920 \pm 84$ & $547 \pm 10$ \\
\hline T1c & $318 \pm 28$ & $217 \pm 10$ & $\mathrm{~T} 7 \mathrm{c}$ & $428 \pm 41$ & $373 \pm 19$ & $\mathrm{~T} 13 \mathrm{c}$ & $734 \pm 57$ & $561 \pm 45$ \\
\hline $\mathrm{T} 2 \mathrm{~s}$ & $1763 \pm 10$ & $1411 \pm 36$ & T8s & $211 \pm 13$ & $125 \pm 21$ & S1c & $82 \pm 5$ & $33 \pm 5$ \\
\hline $\mathrm{T} 2 \mathrm{c}$ & $798 \pm 27$ & $574 \pm 16$ & $\mathrm{~T} 8 \mathrm{c}$ & $145 \pm 17$ & $125 \pm 21$ & $\mathrm{~S} 2 \mathrm{c}$ & $47 \pm 7$ & $41 \pm 5$ \\
\hline $\mathrm{T} 3 \mathrm{~s}$ & $398 \pm 33$ & $377 \pm 48$ & $\mathrm{~T} 9 \mathrm{~s}$ & $369 \pm 29$ & $308 \pm 75$ & $\mathrm{~S} 3 \mathrm{c}$ & $32 \pm 5$ & $22 \pm 5$ \\
\hline $\mathrm{T} 3 \mathrm{c}$ & $430 \pm 7$ & $400 \pm 24$ & T9c & $211 \pm 18$ & $219 \pm 44$ & $\mathrm{~S} 4 \mathrm{c}$ & $84 \pm 5$ & $88 \pm 5$ \\
\hline $\mathrm{T} 4 \mathrm{~s}$ & $812 \pm 12$ & $967 \pm 56$ & $\mathrm{~T} 10 \mathrm{~s}$ & $718 \pm 31$ & $675 \pm 24$ & S5c & $39 \pm 5$ & $29 \pm 14$ \\
\hline $\mathrm{T} 4 \mathrm{c}$ & $448 \pm 23$ & $407 \pm 11$ & $\mathrm{~T} 10 \mathrm{c}$ & $513 \pm 5$ & $675 \pm 24$ & S1Rc & $28 \pm 5$ & $22 \pm 5$ \\
\hline $\mathrm{T} 5 \mathrm{~s}$ & $622 \pm 81$ & $821 \pm 47$ & $\mathrm{~T} 11 \mathrm{~s}$ & $349 \pm 16$ & $316 \pm 7$ & S2Rc & $19 \pm 5$ & $11 \pm 5$ \\
\hline $\mathrm{T} 5 \mathrm{c}$ & $432 \pm 15$ & $434 \pm 74$ & $\mathrm{~T} 11 \mathrm{c}$ & $546 \pm 8$ & $465 \pm 85$ & S3Rc & $36 \pm 5$ & $27 \pm 5$ \\
\hline T6s & $373 \pm 83$ & $970 \pm 92$ & $\mathrm{~T} 12 \mathrm{~s}$ & $1363 \pm 43$ & $1311 \pm 26$ & & & \\
\hline T6c & $871 \pm 81$ & $471 \pm 47$ & $\mathrm{~T} 12 \mathrm{c}$ & $451 \pm 19$ & $518 \pm 38$ & & & \\
\hline
\end{tabular}

between $11 \pm 5$ and $36 \pm 5 \mathrm{mg} \cdot \mathrm{kg}^{-1}$. The total $\mathrm{Cu}$ content in mine tailings is higher in the surface (top $1 \mathrm{~cm}$ ) than in the composite $30 \mathrm{~cm}$ depth. In evaporation-controlled climate, it is possible that highly soluble $\mathrm{Cu}$ species could be mobilized by capillary force to the top mine tailings and once there, their mobility controlled by $\mathrm{pH}$ and sorption processes (Dold, 1999).

In order to determine $\mathrm{Cu}$ speciation and understand its influence to mobility in the environment, a combination of chemical extractions (SEP, phytoaccessibility and bioaccessibility), and XAS was used. Results from SEP showed that up to $80 \%$ of the total $\mathrm{Cu}$ content in mine tailings is in the water soluble fraction (See Table 2). $\mathrm{Cu}$ repartition in tailings followed this trend: Water soluble $>$ Residual $>$ Organic bound $>$ Exchangeable $>$ Fe-Mn oxides bound $>$ Carbonates bound. These results indicate the high mobility of $\mathrm{Cu}$ in the mine tailings. In soils, water soluble $\mathrm{Cu}$ represents the minor fraction. $\mathrm{Cu}$ repartition in soils was Residual $>$ Organic bound $>$ Fe-Mn oxides bound $>$ Carbonates bound $>$ Water soluble $>$ Exchangeable. The results from SEP suggest $\mathrm{Cu}$ in the tailings is present as a highly mobile species and adsorption mechanisms to mineral and amorphous Fe oxides, Mn oxides, and clays do not primarily regulate its mobility. On the other hand, Soil Organic Matter is also a primary factor controlling $\mathrm{Cu}$ mobility (Yang et al., 2014). However, $\mathrm{Cu}$ organic bound fraction in tailings is between $1-17 \%$ and organic matter content is low, on average $1 \%$ (data not shown). $\mathrm{Cu}$ association to $\mathrm{Fe}$-oxide minerals can successfully control the mobility of $\mathrm{Cu}$, because $\mathrm{Cu}$ binding at these minerals is resistant to sequential extractions up to residual fraction (Sracek et al., 2010; Donner et al., 2011). However, in this case, $\mathrm{Cu}$ bound to $\mathrm{Fe}-\mathrm{Mn}$-Oxides only represents between 1 to $7 \%$ in mine tailings, despite of the high $\mathrm{Fe}$ content in the samples (between 108000 to $195000 \mathrm{mg} \cdot \mathrm{kg}^{-1}$ ).

In order to understand how $\mathrm{Cu}$ in tailings and soils may have an impact on the surrounding environment, the bioaccessible and phytoaccessible fractions were determined. According to the Mexican regulations, bioaccessibility is used to quantify the fraction of elements in soils that are soluble in a gastric media. For phytoaccessibility analysis we used an extraction with a solution of LWMOA, in order to simulate a chemical rhizosphere environment. Results showed that in most of the mine tailing samples between 50 and $99 \%$ of total $\mathrm{Cu}$ content is available for plants and bioaccessible (see Table 3 ). In comparison, $\mathrm{Cu}$ in soils has limited availability for plants and no bioccessible $\mathrm{Cu}$ was detected. These results agree with the SEP finding $\mathrm{Cu}$ mostly in the residual and organic bound fractions. The children's oral dose exposition was calculated using values from similar studies: $200 \mathrm{mg} \cdot \mathrm{day}^{-1}$ soil ingest, $52 \mathrm{~h}$ of exposition and $52 \mathrm{~kg}$ weight for a child between 6 and 9 years (CEPIS, 1998). Doses involved in gastrointestinal disorders surpass an intake of $0.0731 \mathrm{mg} \cdot \mathrm{kg} \cdot \mathrm{day}^{-1}$ of $\mathrm{Cu}$ (ATSDR, 2004). All tested tailings surpassed this limit (with a range between 0.123 and $0.549 \mathrm{mg} \mathrm{Cu} \cdot \mathrm{kg} \cdot \mathrm{day}^{-1}$ ). Results suggest that there is high risk for environmental impact on plant community (phytoaccessible $\mathrm{Cu}$ ) and to a lower level for human exposition (bioaccessible $\mathrm{Cu}$ ).

Bulk and spatially resolved synchrotron techniques were used in order to investigate $\mathrm{Cu}$ speciation and associations with other elements in the mine tailings and soil. This approach is very powerful in samples where several chemical species are present (such as tailing and soil samples), the spatially resolved techniques provide confirmation on minor species that are not easy to identify in the bulk measurements. The references used for XANES LCF were $\mathrm{Cu}^{+2} \mathrm{SO}_{4}$ as model for $\mathrm{Cu}^{+2}$ highly soluble species and associated to inorganic and organic matter, $\mathrm{Cu}^{+1} \mathrm{O}_{2}$ to account for $\mathrm{Cu}^{+1}$ species with oxygen ligands, $\mathrm{Cu}^{+1} \mathrm{FeS}_{2}$ to account for $\mathrm{Cu}^{+1}$ species with $\mathrm{S}$ ligands (and also since this is main mineral phase in ore), and finally $\mathrm{Cu}_{3}^{+2} \mathrm{AsO}_{4}(\mathrm{OH})_{3}$ 
Table 2. $\mathrm{Cu}$ Sequential extraction fractions in $\mathrm{mg} \cdot \mathrm{kg}^{-1}$ in mine tailings \pm S.D. and $\%$ from total content of mine tailings (T), soils (S) and reference (R) samples, collected at $1 \mathrm{~cm}$ (s) and $30 \mathrm{~cm}$ (c) depth, grain sizes $<0.25 \mathrm{~mm}(60)$ and $<0.85 \mathrm{~mm}$ (20). nd; no detected.

\begin{tabular}{|c|c|c|c|c|c|c|c|c|c|c|c|c|}
\hline Step & \multicolumn{2}{|c|}{ Water soluble } & \multicolumn{2}{|c|}{ Exchangeable } & \multicolumn{2}{|c|}{ Bound to carbonates } & \multicolumn{2}{|c|}{ Bound to Fe-Mn-Oxides } & \multicolumn{2}{|c|}{ Organic Bound } & \multicolumn{2}{|c|}{ Residual } \\
\hline $\begin{array}{l}\text { Fraction } \\
\text { Sample }\end{array}$ & 60 & 20 & 60 & 20 & 60 & 20 & 60 & 20 & 60 & 20 & 60 & 20 \\
\hline $\mathrm{T} 1 \mathrm{~s}$ & $366 \pm 18(80 \%)$ & $413 \pm 11(71 \%)$ & $21 \pm 5(5 \%)$ & $19 \pm 5(3 \%)$ & nd & nd & $9 \pm 5(2 \%)$ & $8 \pm 5(1 \%)$ & $18 \pm 5(4 \%)$ & $17 \pm 5(3 \%)$ & $36 \pm 9(8 \%)$ & $124 \pm 8(21 \%)$ \\
\hline $\mathrm{T} 1 \mathrm{c}$ & $113 \pm 5(26 \%)$ & $168 \pm 49(46) \%$ & $13 \pm 5(3 \%)$ & $11 \pm 5(6 \%)$ & nd & nd & $8 \pm 5(2 \%)$ & $7 \pm 5(2 \%)$ & $13 \pm 5(3 \%)$ & $15 \pm 5(4 \%)$ & $283 \pm 5(65 \%)$ & $159 \pm 8(44 \%)$ \\
\hline $\mathrm{T} 2 \mathrm{~s}$ & $841 \pm 16(81 \%)$ & $1184 \pm 39(75 \%)$ & $54 \pm 5(5 \%)$ & $33 \pm 5(3 \%)$ & $6 \pm 5(1 \%)$ & $6 \pm 5(<1 \%)$ & $6 \pm 5(1 \%)$ & $7 \pm 5(<1 \%)$ & $18 \pm 5(2 \%)$ & $22 \pm 5(1 \%)$ & $111 \pm 7(11 \%)$ & $310 \pm 29(20 \%)$ \\
\hline $\mathrm{T} 2 \mathrm{c}$ & $519 \pm 23(76 \%)$ & $444 \pm 66(73 \%)$ & $45 \pm 5(5 \%)$ & $48 \pm 5(8 \%)$ & nd & nd & $7 \pm 5(1 \%)$ & $7 \pm 5(1 \%)$ & $19 \pm 5(3 \%)$ & $22 \pm 5(4 \%)$ & $97 \pm 5(14 \%)$ & $79 \pm 9(13 \%)$ \\
\hline T10s & $379 \pm 11(54 \%)$ & $406 \pm 70(63 \%)$ & $34 \pm 5(5 \%)$ & $7 \pm 5(5 \%)$ & nd & nd & $39 \pm 5(6 \%)$ & $26 \pm 6(4 \%)$ & $91 \pm 5(13 \%)$ & $97 \pm 5(15 \%)$ & $125 \pm 5(18 \%)$ & $47 \pm 5(7 \%)$ \\
\hline $\mathrm{T} 10 \mathrm{c}$ & $351 \pm 20(67 \%)$ & $27 \pm 5(6 \%)$ & $7 \pm 5(1 \%)$ & $6 \pm 5(1 \%)$ & nd & nd & $37 \pm 5(7 \%)$ & $36 \pm 5(8 \%)$ & $85 \pm 5(16 \%)$ & $82 \pm 5(17 \%)$ & $33 \pm 5(6 \%)$ & $305 \pm 6(65 \%)$ \\
\hline $\mathrm{T} 12 \mathrm{~s}$ & $1129 \pm 65(83 \%)$ & $1360 \pm 112(87 \%)$ & $52 \pm 5(4 \%)$ & $53 \pm 5(3 \%)$ & $14 \pm 5(1 \%)$ & $13 \pm 5(1 \%)$ & $16 \pm 5(6 \%)$ & $15 \pm 6(1 \%)$ & $42 \pm 23(3 \%)$ & $52 \pm 5(3 \%)$ & $36 \pm 5(3 \%)$ & $67 \pm 24(4 \%)$ \\
\hline $\mathrm{T} 12 \mathrm{c}$ & $333 \pm 21(72 \%)$ & $352 \pm 54(68 \%)$ & $30 \pm 5(7 \%)$ & $26 \pm 5(5 \%)$ & $9 \pm 5(2 \%)$ & $9 \pm 5(2 \%)$ & $15 \pm 5(3 \%)$ & $8 \pm 5(3 \%)$ & $39 \pm 5(9 \%)$ & $37 \pm 5(7 \%)$ & $33 \pm 5(7 \%)$ & $78 \pm 10(15 \%)$ \\
\hline $\mathrm{S} 1 \mathrm{c}$ & $22 \pm 5(21 \%)$ & $17 \pm 5(20 \%)$ & nd & nd & nd & nd & $6 \pm 5(8 \%)$ & nd & $31 \pm 5(31 \%)$ & $14 \pm 5(17 \%)$ & $34 \pm 5(33 \%)$ & $40 \pm 5(48 \%)$ \\
\hline $\mathrm{S} 2 \mathrm{c}$ & nd & nd & nd & nd & nd & nd & nd & nd & $18 \pm 5(41 \%)$ & $11 \pm 5(26 \%)$ & $15 \pm 5(35 \%)$ & $26 \pm 5(61 \%)$ \\
\hline S1Rc & nd & nd & nd & nd & nd & nd & nd & nd & $8 \pm 5(26 \%)$ & $7 \pm 5(34 \%)$ & $13 \pm 5(41 \%)$ & $6 \pm 5(25 \%)$ \\
\hline
\end{tabular}

Table 3. Summary table of chemical extraction $\mathrm{Cu}$ content in $\mathrm{mg} \cdot \mathrm{kg}^{-1} \pm$ S.D. and synchrotron analysis from selected mine tailings (T), soils (S) and reference (R) samples, collected at $1 \mathrm{~cm}(\mathrm{~s})$ and $30 \mathrm{~cm}$ (c) depth, grain sizes $<0.25 \mathrm{~mm}(60)$ and $<0.85 \mathrm{~mm}(20)$. nd; no detected, empty cells; no data available/no analysed.

\begin{tabular}{|c|c|c|c|c|c|c|c|c|c|c|c|c|c|}
\hline Technique & \multicolumn{2}{|c|}{$\mathrm{XRF} \mathrm{mg} \cdot \mathrm{kg}^{-1}$} & \multicolumn{2}{|c|}{ Phytoaccessibiity $\mathrm{mg} \cdot \mathrm{kg}^{-1}$} & Bioaccessibility $\mathrm{mg} \cdot \mathrm{kg}^{-1}$ & \multicolumn{2}{|c|}{ XANES } & \multicolumn{2}{|c|}{$\mu$-XANES } & \multicolumn{2}{|c|}{$\mu$-XRF } & \multicolumn{2}{|c|}{ SEP } \\
\hline $\begin{array}{l}\text { Fraction } \\
\text { Sample }\end{array}$ & 60 & 20 & 60 & 20 & 60 & 60 & 20 & 60 & 20 & 60 & 20 & 60 & 20 \\
\hline $\mathrm{T} 1 \mathrm{~s}$ & $520 \pm 43$ & $1400 \pm 92$ & $611 \pm 10$ & $408 \pm 8$ & $593 \pm 5$ & $\checkmark$ & $\checkmark$ & & & & & $\checkmark$ & $\checkmark$ \\
\hline T1c & $249 \pm 30$ & $370 \pm 37$ & $305 \pm 8$ & $142 \pm 8$ & $296 \pm 5$ & $\checkmark$ & & $\checkmark$ & & $\checkmark$ & $\checkmark$ & $\checkmark$ & $\checkmark$ \\
\hline $\mathrm{T} 2 \mathrm{~s}$ & $1310 \pm 84$ & $547 \pm 48$ & $1700 \pm 14$ & $1398 \pm 18$ & $599 \pm 5$ & $\checkmark$ & & & & & & $\checkmark$ & $\checkmark$ \\
\hline $\mathrm{T} 2 \mathrm{c}$ & $734 \pm 57$ & $561 \pm 45$ & $721 \pm 8$ & $514 \pm 47$ & $601 \pm 5$ & $\checkmark$ & & $\checkmark$ & & $\checkmark$ & & $\checkmark$ & $\checkmark$ \\
\hline $\mathrm{T} 10 \mathrm{~s}$ & & & $414 \pm 5$ & $350 \pm 17$ & $480 \pm 8$ & & & & & & & $\checkmark$ & $\checkmark$ \\
\hline $\mathrm{T} 10 \mathrm{c}$ & & & $15 \pm 5$ & $18 \pm 5$ & $71 \pm 7$ & & & & & & & $\checkmark$ & $\checkmark$ \\
\hline $\mathrm{T} 12 \mathrm{~s}$ & & & $1204 \pm 47$ & $1255 \pm 5$ & $1320 \pm 29$ & & & & & & & $\checkmark$ & $\checkmark$ \\
\hline $\mathrm{T} 12 \mathrm{c}$ & & & $299 \pm 39$ & $373 \pm 10$ & $343 \pm 23$ & & & & & & & $\checkmark$ & $\checkmark$ \\
\hline S1c & $102 \pm 16$ & $105 \pm 16$ & nd & nd & $12 \pm 5$ & $\checkmark$ & & $\checkmark$ & & $\checkmark$ & & $\checkmark$ & $\checkmark$ \\
\hline $\mathrm{S} 2 \mathrm{c}$ & & & $12 \pm 7$ & $6 \pm 5$ & nd & & & & & & & $\checkmark$ & $\checkmark$ \\
\hline S1Rc & & & nd & nd & nd & & & & & & & $\checkmark$ & $\checkmark$ \\
\hline
\end{tabular}

(clinoclase) as suggested by the correlation of $\mathrm{As}$ and $\mathrm{Cu}$ in $\mu \mathrm{XRF}$ map from sample T1c20 (see Figure 2(A) R1, R2). The As-Cu correlation can be observed in the tricolor image Figure $2 \mathrm{~A}$ in pixels with a yellow to orange color obtained by the overlay of $\mathrm{Cu}$ (green) and $\mathrm{As}$ (red). The total content of As in the mine tailings reaches up to $12000 \mathrm{mg} \cdot \mathrm{kg}^{-1}$ in the tailings and $300 \mathrm{mg} \cdot \mathrm{kg}^{-1}$ in soils, geochemical studies of As are also being conducted to investigate its mobility. Figure 1 shows the XANES LCF results obtained with the use of the selected references for one mine tailing and one soil, samples T1c60 and S1c60. Results from all samples analyzed by bulk-XANES are shown in Table 4. Results showed that $\mathrm{Cu}$ in mine tailing samples is mainly present as $\mathrm{Cu}^{2+}$ species (which as suggested by SEP is a highly mobile species) and clinoclase $\left(\mathrm{Cu}_{3}\left(\mathrm{AsO}_{4}\right)(\mathrm{OH})_{3}\right)$. XRF maps suggest $\mathrm{Cu}$ in the tailing soluble fraction could not only be present as $\mathrm{CuSO}_{4}$, since $\mathrm{S}$ is mainly co-localized with $\mathrm{Ca}$ (Pearson correlation 0.867). This $\mathrm{Cu}^{+2}$ highly soluble species in tailings is potentially a mixture of $\mathrm{CuSO}_{4}$ of varied crystallinities and hydration levels and forming soluble $\mathrm{Cu}$ complexes with organic acids derived from microorganism exudates (Ebena et al., 2007; Xie et al.,
2010). The percentages of clinoclase obtained in the fit might not be accurate since clinoclase presents a XANES spectrum similar to other $\mathrm{Cu}^{+2}$ species (bound to organic matter and adsorbed to oxides), hence it is difficult to accurately distinguish $\mathrm{Cu}^{+2}$ species based on their XANES signal. Another $\mathrm{Cu}$ arsenate reference (olivenite) was tested but fittings were of better quality with clinoclase. The presence of clinoclase requires confirmation and for that spatially resolved synchrotron micro X-ray Diffraction experiments will be performed on these samples in a future experiment. $\mathrm{Cu}^{+1}$ species bound to oxygen ligands (as in $\left.\mathrm{CuO}_{2}\right)$ were rarely detected in the mine tailing samples $(5 \%$ in T1s60), which confirms $\mathrm{Cu}^{+1}$ is not an abundant species. The presence of another low abundance species $\left(\mathrm{Cu}^{+1} \mathrm{FeS}_{2}\right.$, chalcopyrite) in the tailing samples was confirmed with the use of $\mu$-XRF mapping and $\mu$-XANES (see Figure 2 $(\mathrm{B}, \mathrm{D}))$. Chalcopyrite is commonly distributed in the earth crust, but due to its low solubility it does not represents a risk for Cu mobility in natural conditions (Dold, 1999). The soil XANES LCF results showed a decreased contribution of $\mathrm{Cu}^{+2}$ mobile species and higher contribution from the reference $\mathrm{Cu}^{+2}$ arsenate (clinoclase). This $\mathrm{Cu}^{+2}$ species has a 

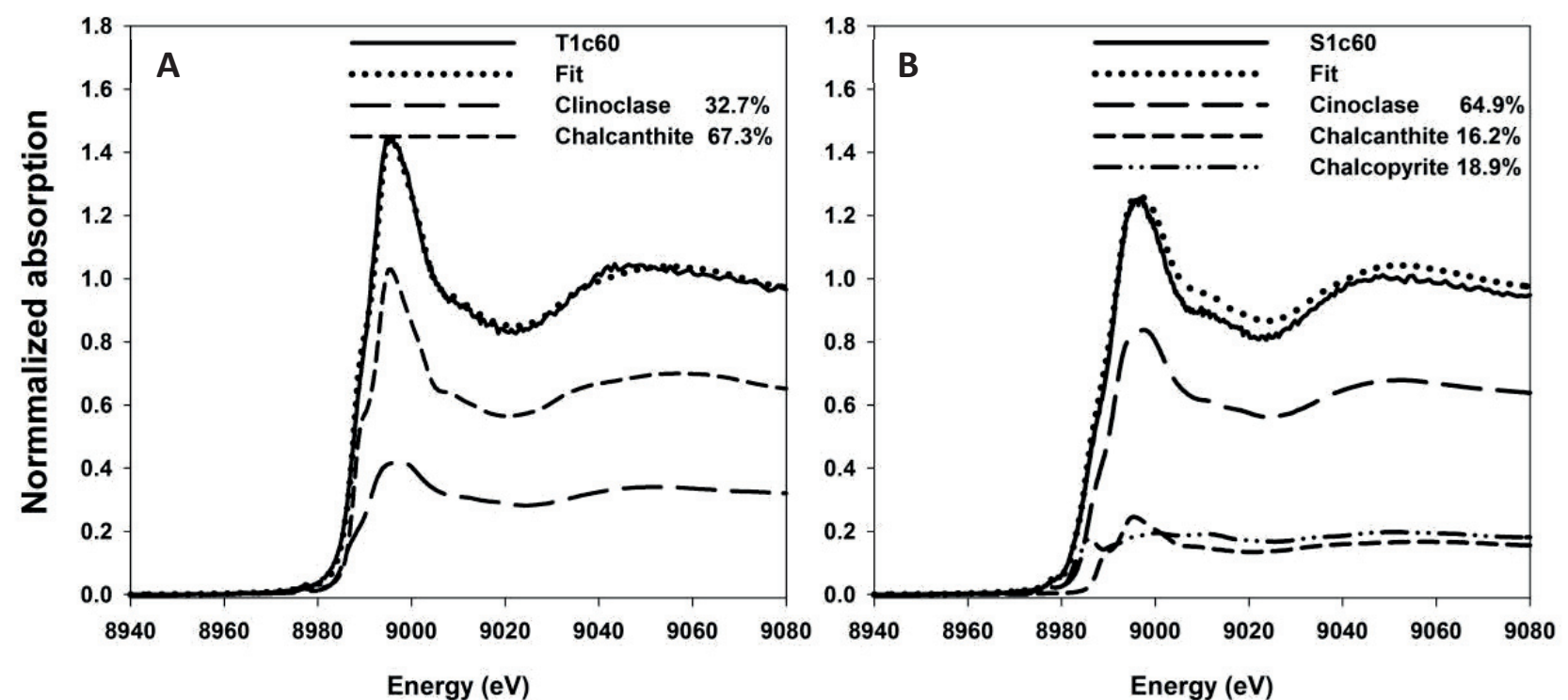

Figure 1. Linear combination analysis of representative tailing (A) and soil (B) samples, using clinoclase $\left(\mathrm{Cu}_{3} \mathrm{AsO}_{4}(\mathrm{OH})_{3}\right)$, chalcanthite $\left(\mathrm{CuSO} \cdot 5 \mathrm{H}_{2} \mathrm{O}\right)$ and chalcopyrite $\left(\mathrm{CuFeS}_{2}\right)$ as reference spectra.

Table 4. Weight of components from Bulk XANES Linear combination analysis in some tested mine tailings (T) and soils (S) samples, collected at $1 \mathrm{~cm}$ (s) and $30 \mathrm{~cm}$ (c) depth, grain size $<0.25 \mathrm{~mm}(60)$.

\begin{tabular}{cccccc}
\hline \multicolumn{5}{c}{ Components } & Results \\
\hline Sample & $\begin{array}{c}\text { Clinoclase } \\
\mathrm{Cu}_{3} \mathrm{AsO}_{4}(\mathrm{OH})_{3}\end{array}$ & $\begin{array}{c}\text { Chalcanthite } \\
\mathrm{CuSO}_{4} \cdot 5 \mathrm{H}_{2} \mathrm{O}\end{array}$ & $\begin{array}{c}\text { Chalcopyrite } \\
\mathrm{CuFeS}_{2}\end{array}$ & $\mathrm{Cu}_{2} \mathrm{O}$ & R-factor \\
\hline $\mathrm{T} 1 \mathrm{~s} 60$ & 0.342 & 0.606 & 0 & 0.052 & 0.0018 \\
$\mathrm{~T} 1 \mathrm{c} 60$ & 0.327 & 0.673 & 0 & 0 & 0.0015 \\
$\mathrm{~T} 2 \mathrm{~s} 60$ & 0.404 & 0.596 & 0 & 0 & 0.0013 \\
$\mathrm{~T} 2 \mathrm{c} 60$ & 0.225 & 0.775 & 0 & 0 & 0.002 \\
$\mathrm{~S} 1 \mathrm{c} 60$ & 0.649 & 0.162 & 0.189 & 0 & 0.008 \\
\hline
\end{tabular}

low solubility constant $\left(7.6 \times 10^{-36}\right)$ (Magalhaes and Pedrosa de Jesus, 1988) and it could explain the low water soluble and exchangeable values of $\mathrm{Cu}$ obtained by SEP. Clinoclase occurs in arsenate and sulphate rich environments at oxidized conditions, the most common secondary mineral in this environment is olivenite at slightly acidic $\mathrm{pH}(4-6)$ but around neutral $\mathrm{pH}$, clinoclase is predominant (Williams, 1990). In soil samples pH range is 7.3 - 8.2. In soils the mobility of $\mathrm{Cu}$ is possibly controlled by the formation of secondary minerals (Clinoclase) or adsorption to organic matter. In addition to this, $\mu$-XANES spectra from the soil composite sample (S1c60) presents a near-edge feature characteristic of $\mathrm{Cu}^{+1}$ (as in $\mathrm{CuO}_{2}$ ) which confirms the presence of $\mathrm{Cu}^{+1}$ species bound to oxygen ligands and colocalized with $\mathrm{Fe}$ (see Figure 2 (C, D)). This result suggests the formation of $\mathrm{Cu}^{+1} \mathrm{FeO}_{2}$ in the soil sample (Sukeshini et al., 2000). The bulk XANES analysis of the soil sample also suggests $\mathrm{Cu}^{+1} \mathrm{FeS}_{2}$ (chalcopyrite) is present in the soil and the origin of this species might be linked to mechanical transport of particles (water and wind erosion).

\section{Conclusions}

In summary, $\mathrm{Cu}$ is present as a highly $\mathrm{Cu}^{+2}$ mobile species in the mine tailings that could be moving towards surrounding soil in water solution and via wind and water erosion. In soils $\mathrm{Cu}$ is predominantly $\mathrm{Cu}^{+2}$ but as confirmed by SEP in the form of a less mobile $\mathrm{Cu}$ species. The formation of a $\mathrm{Cu}$-arsenate species is likely due to the high content of As and co-localization observed from $\mu \mathrm{XRF}$ maps. However, adsorption to amorphous and crystalline Fe and $\mathrm{Mn}$ oxides and associations to organic matter are likely to occur in the soil. The presence of $\mathrm{Cu}^{+1}$ species as oxides and sulphides was also confirmed by $\mu \mathrm{XRF} / \mathrm{XANES}$ results but represent only a minor fraction in both tailing and soil. Since, water soluble and exchangeable $\mathrm{Cu}$ in soil is low; the highly mobile $\mathrm{Cu}$ from the tailings could be reaching further from our tested sampling site and even filtrating further than the $30 \mathrm{~cm}$ sampled depth in the soil. The results of this research report also on the high potential impact to plants in this site since phytoaccessible $\mathrm{Cu}$ is higher than $50 \%$. 

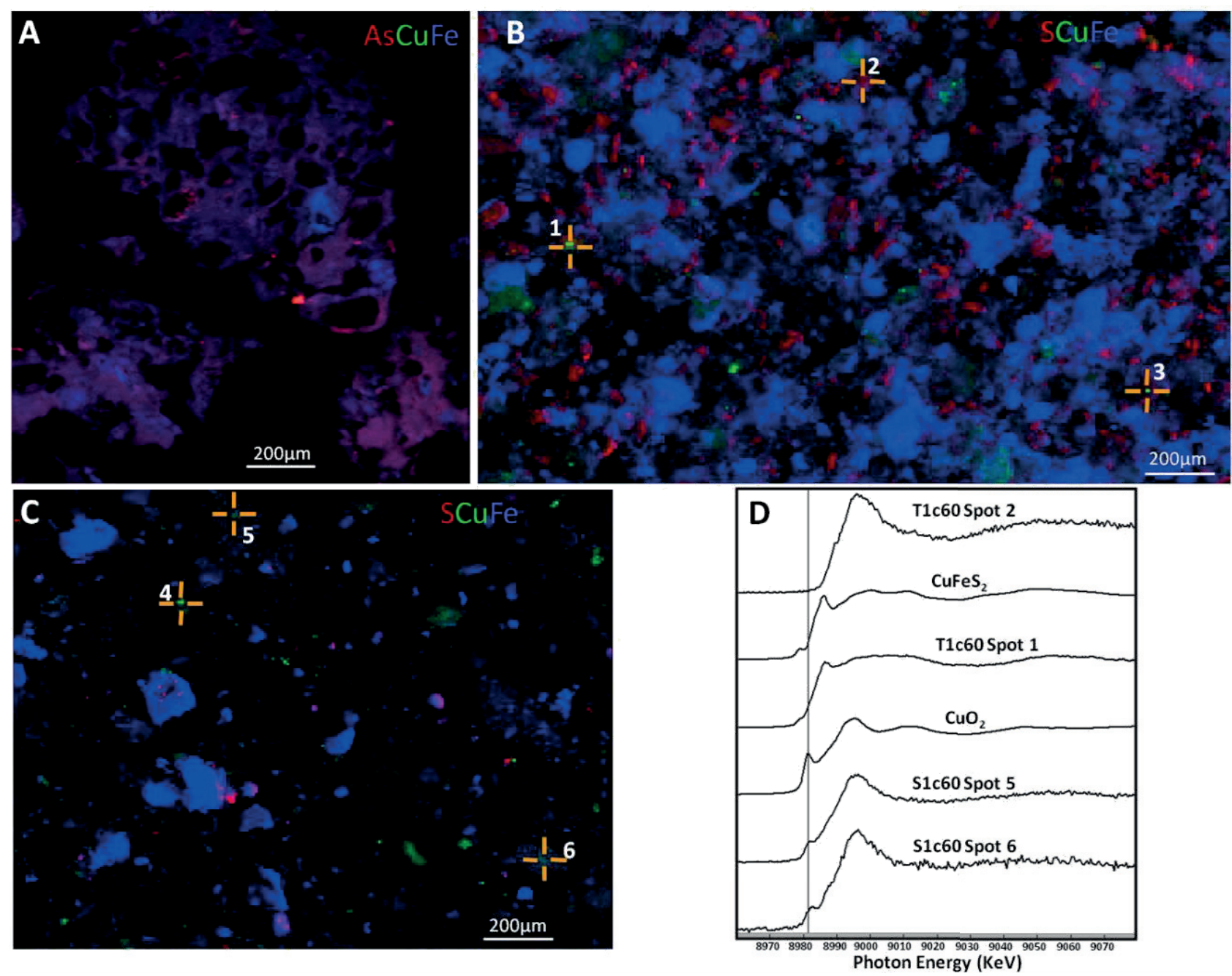

Figure 2. $\mu$-XRF maps and $\mu$-XANES spectra. A) $\mu$-XRF map at $12.1 \mathrm{keV}$ incident energy from sample T1c20 (embedded thin section). B) $\mu$-XRF map at $9.2 \mathrm{keV}$ incident energy from sample T1c60. C) $\mu$-XRF map at $9.2 \mathrm{keV}$ incident energy from sample S1c60. D) $\mu$-XANES spectra from label spots indicated in $\mathrm{B}$ and $\mathrm{C}$ and reference compounds $\mathrm{CuFeS}_{2}$ and $\mathrm{CuO}_{2}$.

Further experiments should be performed in order to quantify $\mathrm{Cu}$ concentration in plants from the region and determine the impact to plant community. For human health, this site is also potential threat due to the elevated $\mathrm{Cu}$ content which surpasses in some cases the dose involved in gastrointestinal diseases and liver damage. More sampling points should be analysed using the present approach (SEP-XAS- $\mu$-XRF/ XANES) in order to better understand the mobility of $\mathrm{Cu}$ in the site and the impact on environmental and human health. However, one disadvantage of synchrotron based techniques is the lack of availability of the instruments and the short time of experimentation which is allocated for each user group. The present work has illustrated the importance of a multianalytical, multiscale approach for the understanding of geochemical processes that are involved in the mobilization and speciation of potentially toxic elements (such as $\mathrm{Cu}$ ).

\section{Acknowledgements}

The authors wish to acknowledge to Consejo Nacional de Ciencia y Tecnología (CONACyT; Doctoral scolarship 328291), International Atomic Energy Agency (IAEA; 17114) and the International Centre for Theoretical Physics (ICTP; 20120039, 20125109, 20130336). Elettra Synchrotron Light Source, XAFS beamline, ESRF, beamline ID-21, and ALS beamline 10.3.2. and Red Temática de Usuarios de Luz Sincrotrón (Red TULS). The ALS is supported by the Director, Office of Science, Office of Basic Energy Sciences, of the U.S. Department of Energy under Contract No. DE-AC02-05CH11231. The authors also wish to thank Universidad Autónoma de San Luis Potosí and Monica Morales director of the Mineralogy Museum Eduardo Villaseñor Söhle. 


\section{References}

Agency for Toxic Substances \& Disease Registry (ATSDR), 2004, Dorsey, A., Ingerman, L., Swarts, S., Toxicological profile for copper, U.S. Department of Health and Human Services, ATSDR toxicological profiles, $202 \mathrm{p}$.

Alaoui-Sossé, B., Genet, P., Vinit-Dunand, D.F., Marie-Laure, T., Epron, D., Pierre-Marie, B., 2004, Effect of copper on growth in cucumber plants (Cucumis sativus) and its relationship with carbohydrate accumulation and changes in ion contents: Plant Science, 166, 1213-1218.

Anthony, W.J., Bideaux, A.R., Bladh K. W., Nichols, M.C., 2003, Handbook of Mineralogy, Borates, carbonates, sulfates, USA, Mineralogical Society of America, $791 \mathrm{p}$.

Belmonte Serrato, F., Romero Diáz, A., Alonso Sarría, F., Moreno Brotóns, J., Rojo López, S., 2010, Afección de suelos agrícolas por metales pesados en áreas limítrofes a explotaciones mineras del sureste de España: Papeles de Geografía, 51-52, 45-54.

Bowie, S.H.U., Thornton, F.R.S., 1985, Environmental Geochemistry and Health: Dordrecht, Holland, D. Riedel Publishing Company, 59-95.

Carrillo-Chávez, A., Salas-Megchún, E., Levresse, G., Muñoz-Torres C., Pérez-Arvizu O., Gerke T., 2014, Geochemestry and mineralogy of mine-wastematerial from a "skarn-type" deposit in central Mexico: Modeling geochemical controls of metals in the surface environment: Journal of Geochemical Exploration, 144 part A, 28-36.

Centro Panamericano de Ingeniería Sanitaria (CEPIS), 1998, Mejía, J., Carrizales., L., Díaz-Barriga, Evaluación de la exposición en sitios peligrosos. Zona minera de Villa de la Paz - Matehuala, Lima, Perú, Centro Panamericano de Ingeniería Sanitaria, Reporte técnico, 4, 1 p.

Cieśliński, G., Van Ress, K.C.J., Szmigielska, A.M., Krishnamurti, G.S.R., Huang, P.M., 1998, Low-molecular-weight organic acids in rhizosphere soils of durum wheat and their effect on cadmium bioaccumulation: Plant and soil, 203 (1), 109-117.

Dold, B., 1999, Mineralogical and geochemical changes of copper flotation tailings in relation to their original composition and climatic setting - implications for acid mine drainage and element mobility: Genève, Terre \& Environment, $\mathrm{PhD}$ thesis, 18, 3125, $230 \mathrm{p}$.

Donner, E., Howard, L.D., de Jonge, D.M, Paterson, D., Cheah, H.M., Naidu, R., Lombi, E., 2011, X-ray absorption and micro X-ray fluorescence spectroscopy investigation of copper and zinc speciation in biosolids: Environmental Science \& Technology, 45 (17), 7249-7257.

Ebena, G., Hagberg, J., Carlsson, E., 2007, Origin and distribution of low molecular weight organic acids and bacteria in a depth profile of a soil covered tailings impoundment in northern Sweden: Journal of Geochemical Exploration, 92 (2-3), 186-195.

Freedman, H.J., Weiner, R.J., Peisach, J., 1986, Resistance to copper toxicity of cultured hepatoma cells: The Journal of Biological Chemistry, 261 (25), 11840-11848.

International Atomic Energy Agency (IAEA), 2011, Kump, P., Necemer, M., Rupnik, Z., Pelicon, P., Ponikvar, D., Vogel-Mikus, K., Regvar, M., Pongrac, P., Improvement of the XRF quantification and enhancement of the combined applications by EDXRF and micro-PIXE, Integration of nuclear spectrometry methods as a new approach to material research: Vienna, Austria, International Atomic Energy Agency, Technical report, 1669, $157 \mathrm{p}$.

Magalhaes, M.C.F., Pedrosa de Jesus, J.D., 1998, The chemistry of some secondary arsenate minerals of $\mathrm{Cu}(\mathrm{II}), \mathrm{Zn}(\mathrm{II})$ and $\mathrm{Pb}$ (II): Mineralogical Magazine, 52, 679-690.

Mamindy-Pajany, Y., Sayen, S., Mosseelmans, J.F.W., Guillon, E., 2014, Copper, nickel and zinc speciation in a biosolid-amended soil: $\mathrm{pH}$ adsorption edge, $\mu$-XRF and $\mu$-XANES investigations: Environmental Science \& Technology, 48 (13), 7237-7244.

Marcus, M.A., MacDowell, A.A., Celestre, R., Manceau A., Miller, T., Padmore, H.A., Sublett, R.E., 2004, beamline 10.3.2 at ALS: a hard $\mathrm{X}$ - ray microprobe for environmental and material sciences: Journal of Synchrotron Radiation, 11, 239-247.
Mohanty, N., Vass, I., Demeter, S., 1989, Copper toxicity affects photosystem II electron transport at the secondary quinone acceptor QB: Plant Physiology, 90 (1), 175-179.

Montenegro, G., Fredes, C., Mejía, E., Bonomelli, C., Olivares, L., 2009, Contents of heavy metals in soils near Chilean copper mining tailing: Agrociencia, 43 (4), 427-435.

Necemer, M., Kump, P., Scancar, J., Jacimovic, R., Simcic, J., Pelicon P., Budnar, M., Jeran Z., Pongrac, P., Regvar, M., Vogel-Mikus, K., 2008, Application of X-ray fluorescence analytical techniques in phytorremediation and plant biology studies: Spectrochimica Acta Part B, 63, 1240-1247.

Plenderleith, R.W., Bell, L.C., 1990, Tolerance of twelve tropical grasses to high soil concentrations of copper: Tropical Grasslands, 24, 103-110.

Ravel, B., Newville, M., 2005, Athena, Arthemis, Hephaestus; data analysis for X-ray absorption spectroscopy using IFEFFIT: Journal of Synchrotron Radiation, 12, 537-541.

Ryan, B.M., Kirby, J.K., Degryse, F., Harris, H., McLaughlin, M.J., Scheiderich, K., 2013, Copper speciation and isotopic fractionation in plants: uptake and translocation mechanisms: New Phytologist, 199 (2), 367-378.

Secretaría de Medio Ambiente y Recursos Naturales (SEMARNAT), 2005, Estudio previo justificativo para el establecimiento del área natural protegida, Reserva de la Biosfera "Sierra Gorda de Guanajuato", México, Comisión Nacional de Áreas Naturales Protegidas, 281 p.

Secretaria de Medio Ambiente y Recursos Naturales (SEMARNAT), 2007, Criterios para determinar las concentraciónes de remediación de suelos contaminados por arsénico, bario, berilio, cadmio, cromo hexavalente, mercurio, níquel, plata, plomo, selenio y/o vanadio, (NOM-147-SEMARNAT/SSA1): México, D.F., Diario Oficial de la Federación, 2 de Marzo de 2007, 86 p.

Solé, V.A., Papillon, E., Cotte, M., Walter, Ph., Susini, J., 2007, A multiplataform code for the analysis of energy-dispersive X-ray fluorescence spectra: Spectrochimica Acta Part B, 62 (1), 63-68.

Sracek, O., Milhaljevic, M., Kríbek, B., Majer, V., Veselovský, F., 2010, Geochemistry and mineralogy of $\mathrm{Cu}$ and $\mathrm{Co}$ in mine tailings at the Copperbelt Zambia: Journal of African Earth Sciences, 57 (1-2), 14-30.

Stern, B.R., Solioz, M., Krewski, D., Aggett, P., Aw, T.C., Baker, S., Crump, K., Dourson, M., Haber, L., Hertzberg, R., Keen, C., Meek, B., Rudenko, L., Schoeny, R., Slob, W., Starr, T., 2007, Copper and human health: Biochemistry, genetics, and strategies for modeling dose-response relationships: Journal of Toxicology and Environmental Health, 10 (3), 157-222.

Sukeshini, A.M., Koboyashi, H., Tabuchi, M., Kageyama, H., 2000, Physicochemical characterization of $\mathrm{CuFeO}_{2}$ and lithium intercalation: Solid State Ionics, 128 (1-4), 33-41.

Tessier, A., Campbell, P.G.C., Bisson, M., 1979, Sequential extraction procedure for the speciation of particulate trace metals: Analytical Chemistry, 51 (7), 844-851.

United States Environmental Protection Agency (US-EPA), 1996, acid digestion of sediments, sludges, and soils (METHOD 3050B): USA., Environmental Protection Agency. Method study 3050b, 12 p.

Van-Grieken, R.E., 1993, Handbook of X-ray Spectrometry: Methods and Techniques, in Van-Grieken, R.E., Markowicz, A.A. (eds.), Drugs and the pharmaceutical sciences practical spectroscopy series: USA, Michigan, Marcel Dekker, 181-239.

Vekemans, B., Janssens, K., Vincze, L., Adams, F., Van-Espen, P., 1994, Analysis of X-ray spectra by iterative least squares (AXIL): new developments: X-ray spectrometry, 23 (6), 278-285.

Williams, P.A., 1990, Oxide Zone Geochemistry, Series in inorganic chemistry Prentice-Hall, USA, California, Ellis Horwood, $286 \mathrm{p}$.

Xie, X., Fu, J., Wang, H., Liu, J., 2010, Heavy metal resistance by two bacteria strains isolated from a copper mine tailing in China: African Journal of Biotechnology, 9 (26), 4056-4066.

Yang, J., Liu, J., Dynes, J.J., Peak, D., Regier, T., Wang, J., Zhu, S., Shi, J., Tse, J.S., 2014, Speciation and distribution of copper in mine soils using multiple synchrotron-based bulk and microscopic techniques: Environmental Science and Pollution Research, 21 (4), 2943-2954. 
Yao-Guang, G., Peng, H., Wu-Gang, Z., Xue-Wu, Y., Feng-Xia, F., HuanLi, W., Jian-She, L., Zhao-Hui, W., 2013, Leaching of heavy metals from Dexing copper mine tailings pond: Transactions of Nonferrous Metals Society of China, 23 (10), 3068-3075.

Zebo, L., Qihua, S., Jianfeng, Z., Guancai, C., Ying, W., Xianhu, L.,, 2012, Soil copper distribution in Tongling mine tailing dam, China, (Summary), in International Conference on Biomedical Engineering and Biotechnology: Macau, China, Institute of Electrical and Electronics Engineers, 1672-1675.
Manuscript received: October 27, 2014

Corrected manuscript received: March 18, 2015.

Manuscript accepted: March 28, 2015. 